\title{
ANALISIS PENDAPATAN USAHATANI PADI BERDASARKAN STATUS PENGUASAAN LAHAN SAWAH IRIGASI DI KECAMATAN MEUREUDU KABUPATEN PIDIE JAYA
}

\author{
( Analisys of Rice Farmers Incomes Based on Irrigated Land Tenure Status in The Sub- \\ District of Meureudu Pidie Jaya Regency ) \\ Cut Idatul Fitriah ${ }^{1}$, Widyawati ${ }^{1}$, Sofyan ${ }^{1 *}$ \\ ${ }^{1}$ Program Studi Agribisnis, Fakultas Pertanian, Universitas Syiah Kuala
}

\begin{abstract}
Abstrak. Indonesia merupakan negara agraris karena mayoritas penduduknya bermata pencaharian sebagai petani. Tingginya pertambahan sehingga jumlah penduduk yang bertambah tidak sebanding dengan luas lahan yang tetap. Akibatnya lahan pertanian banyak dialih fungsikan menjadi areal non pertanian. Pada tahun 2017 rata-rata luas lahan yang dikuasai per RTP yaitu $2.589 \mathrm{~m}^{2}$. Akibatnya petani yang memiliki lahan sempit atau bahkan tidak memiliki lahan sawah sendiri akan memilih menggarap lahan sawah orang lain untuk menambah pendapatannya. Hal ini menyebabkan munculnya status penguasaan lahan petani pemilik penggarap, penyewa, penyakap dan pemegang gadai. Tujuan dari penelitian ini adalah untuk mengetahui pendapatan yang diperoleh pada usahatani padi sawah berdasarkan status penguasaan lahan petani pemilik-penggarap, petani penyakap, petani penyewa dan petani pemegang gadai di Kecamatan Meureudu Kabupaten Pidie Jaya. Penentuan lokasi penelitian ini dilakukan secara sengaja (purposive sampling). Selanjutnya teknik pengambilan sampel ditentukan dengan cara stratified random sampling. Pengambilan sampel berdasarkan sistem penguasaan lahan sebesar 15\%. Pengujian hipotesis dilakukan dengan menggunakan analisis biaya produksi, penerimaan, pendapatan, R/C Ratio dan Break Event Point (BEP). Hasil analisis pendapatan tertinggi yaitu pada petani dengan status lahan milik sebesar Rp. 8.322.235/Ha/MT, selanjutnya pendapatan petani dengan status lahan sewa yaitu sebesar Rp. 8.201.947 /Ha/MT. Sedangkan pendapatan petani dengan status lahan gadai sebesar Rp. 8.075.218/Ha/MT. Pendapatan terendah yaitu pada status lahan sakap mencapai Rp. 8.029.151/Ha/MT. Berdasarkan hasil perhitungan R/C Usahatani padi sawah beririgasi pada petani pemilik-penggarap dan petani penyewa lebih menguntungkan dibandingkan dengan petani pemegang gadai dan petani penyakap.
\end{abstract}

Kata kunci: Pendapatan, Status Penguasaaan Lahan, Petani Padi

\begin{abstract}
Indonesia is an agrarian country as the majority of the population worked as farmers. A significant population growth is not comparable with the availability of land area. Therefore, many of agricultural lands have been converted into non-agricultural areas. In 2017, the average of land area was controlled by RTP and reached 2,589 $\mathrm{m}^{2}$. Hence, the farmer who own small land or landless farmer tends to cultivate land of others in order to get the income. Later, it comes up with the term of tenure status; farmer, tenant farmer, sharecropper, and pawn holder. The aim of this study is to know the income of farmer, tenant farmer, sharecropper, and pawn holder in rice farming business based on the tenure status at Meureudu, Pidie Jaya. The location of this study is determined by conducting purposive sampling method. The sampling technique is conducted by using stratified random sampling. The sample is selected based on the percentage of tenure system at $15 \%$. The hypothesis testing is conducted by analyzing the production cost, revenue, income, R/C Ratio and Break Event Point (BEP). The findings indicate that the analysis of the highest income is earned by the farmers who own the land of Rp. 8.322.235/Ha/MT and then the income of tenant farmers with the status of rental land of Rp. 8.201.947/Ha/MT. While the income of farmers with pawn land status are Rp. 8.075.218/Ha/MT. The lowest income is earned by sharecroppers of Rp. 8.029.151/Ha/MT. Based on the calculation of R/C; the irrigated paddy farming on farmer and tenant farmers is more profitable than sharecroppers and pawn holders.
\end{abstract}

Key words: Income, Status of land tenure, rice farmer

*Corresponding author: Sofyansamsudin@unsyiah.ac.id

JIM Pertanian Unsyiah - AGB, Vol. 3, No. 4, November 2018: 429-441 


\section{PENDAHULUAN}

Indonesia merupakan negara agraris karena mayoritas penduduknya bermata pencaharian sebagai petani. Pada tahun 2010 tercatat jumlah penduduk Indonesia mencapai 237,6 juta jiwa sementara tahun 2016 jumlah penduduk mencapai 258,9 juta jiwa. Tingginya pertambahan sehingga jumlah penduduk yang bertambah tidak sebanding dengan luas lahan yang tetap. Akibatnya lahan pertanian banyak dialih fungsikan menjadi areal non pertanian. Pada tahun 2017 Luas tanam padi sawah beririgasi di Kecamatan Meureudu mencapai 1.162 hektar yang tersebar di 30 desa dengan rata-rata luas lahan yang dikuasai per RTP yaitu 2.589 $\mathrm{m}^{2}$. Hal ini sangat berbeda jauh dengan tahun 2009 yang tercatat rata-rata luas lahan padi sawah beririgasi yang dikuasai per RTP mencapai $5.288 \mathrm{~m}^{2}$. Akibatnya petani yang memiliki lahan sempit atau bahkan tidak memiliki lahan sawah sendiri akan memilih menggarap lahan sawah orang lain untuk menambah pendapatannya. Hal ini menyebabkan munculnya status penguasaan lahan petani pemilik penggarap, penyewa, penyakap dan pemegang gadai.

Setiawan (2006), menemukan beberapa faktor yang mempengaruhi semakin merosotnya penguasaan lahan. Faktor-faktor tersebut diantaranya adalah (1) faktor ekonomi (misal: lemahnya proporsi pendapatan usahatani terhadap total penerimaan RTP), (2) faktor alam (misal: banjir, kekeringan, erosi, pencemaran, iklim, cuaca, serangan hama penyakit yang semakin intensif, luas dan bervariasi sehingga sulit untuk diprediksi dan dikendalikan), (3) kebijakan pemerintah tidak mengutamakan pertanian, (4) akses petani terhadap penggunaan lahan pertanian yang tersedia, (5) jumlah tanggungan keluarga (anak-anak pewaris tidak mendapatkan pekerjaan di luar sektor pertanian, akibatnya lahan warisan dibagi-bagi hingga jelas batas-batas kepemilikannya), (6) faktor sosial ekonomi (misalnya: tingginya biaya sekolah anak) dan (7) terbatasnya kredit modal kerja di sektor pertanian.

Secara umum bentuk penguasaan lahan dikelompokkan menjadi dua yakni pemilik dan bukan pemilik. Pemilik berarti petani yang menggarap lahan sawah miliknya sendiri, sedangkan bukan pemilik yaitu petani yang mengusahakan sawah milik orang lain. Bukan pemilik terdiri atas sewa, bagi hasil dan gadai. Menurut UUPA tahun 1960, penguasaan hak milik lahan adalah lahan turun menurun yang dapat dimiliki seseorang atas sebidang tanah baik berasal dari warisan, pembelian atau hibah dari orang lain (Winarso, 2012).

Menurut Suharso (2002) dalam tulisannya tentang "Tanah, Petani, Politik Perdesaan" status pengusaan lahan yang dipedesaan hanya dilihat dari 4 golongan, yaitu: (1) Petani pemilik penggarap yaitu golongan petani yang menggarap lahan miliknya sendiri. (2) Petani penyewa yaitu golongan petani yang menggarap lahan milik orang lain dengan cara menyewa, namun segala resiko dalam usahataninya ditanggung oleh penyewa. (3) Petani penyakap adalah golongan petani yang mengerjakan lahan orang lain dengan sistem bagi hasil sesuai dengan perjanjian yang telah disepakati sebelumnya. (4) Petani status gadai yaitu golongan petani yang menggarap lahan milik orang lain yang menerima uang gadai darinya. Teori dasar yang dapat dipakai untuk menerangkan tingkah laku ekonomi dari petani pemilik-penggarap, petani penyewa, petani pemegang gadai dan petani penyakap adalah teorinya Marshall yang dikenal juga dengan "The Taxequivalent Approach". Marshall dengan menggunakan analisis marjinal pada bagi hasil tanaman (sharecropping), menyatakan karena petani bagi hasil hanya menerima sebagian produk marjinal dari masukan yang dikeluarkan (dalam hal ini tenaga kerja), maka petani dengan status penguasaan lahan ini tidak punya rangsangan yang cukup (Mudakir, 2011). Tujuan akhir usahatani keluarga adalah pendapatan keluarga petani yang terdiri atas laba, upah tenaga keluaraga dan bunga modal sendiri. Pendapatan yang dimaksud adalah selisih antara nilai produksi dikurangi dengan biaya yang betul-betul dikeluarkan oleh petani. Laba, upah

Analisis Pendapatan Usahatani Padi Berdasarkan Status Penguasaan Lahan Sawah Irigasi Di Kecamatan

Meureudu Kabupaten Pidie Jaya (Cut Idatul Fitriah, Sofyan, Widyawati)

Jurnal Ilmiah Mahasiswa Pertanian Unsyiah, Vol. 3, No. 4, November 2018: 429-441 
tenaga kerja dan bunga modal sendiri dianggap satu kesatuan yang tidak dapat dipisahkan lagi. Sementara perusahaan pertanian tuajuan akhirnya adalah keuntungan atau laba yang sebesarbesarnya, yaitu selisih antara nilai hasil produksi dikurangi dengan biaya (Suratiyah,2015).

Penelitian sebelumnya Prisilia dan Esry (2017) mengemukakan bahwa Status penguasaan lahan mempengaruhi rata-rata pendapatan yang diterima oleh petani padi sawah. Pendapatan usahatani terbesar adalah petani pemegang gadai yaitu Rp. 14.652.066 dan pendapatan diperoleh oleh petani milik sendiri yaitu Rp 10.519.778, sedangkan pendapatan yang terendah diperoleh oleh petani penyakap yaitu sebesar Rp 8.591.073. Hal dikarenakan penggunaan pestisida yang besar oleh petani penyakap. Bila dilihat dalam rata-rata pendapatan yang diterima masing-masing petani menunjukkan adanya perbedaan yang nyata antara ketiga status penguasaan lahan petani milik sendiri, petani penyakap dan petani pemegang gadai. Dengan demikian diharapkan pemanfaatan lahan usahatani yang terbatas itu sebagai salah satu faktor produksi terpenting sehingga dapat diusahakan oleh petani dan memberi manfaat yang besar bagi semua lapisan masyarakat khususnya petani. Tujuan dari penelitian ini adalah untuk mengetahui pendapatan yang diperoleh pada usahatani padi sawah berdasarkan status penguasaan lahan petani pemilik-penggarap, petani penyakap, petani penyewa dan petani pemegang gadai di Kecamatan Meureudu Kabupaten Pidie Jaya.

\section{METODE PENELITIAN}

Penelitian ini dilakukan di Kecamatan Meureudu Kabupaten Pidie Jaya, tepatnya berada di dua desa yaitu desa Manyang Lancok dan desa Rumpuen. Objek dari penelitian ini berfokus pada petani padi sawah irigasi dengan status lahan petani pemilik-penggarap, petani penyakap, petani penyewa dan petani pemegang gadai. Sedangkan ruang lingkup dari penelitian ini terbatas pada masalah pendapatan petani padi sawah irigasi menurut status penguasaan lahan di Kecamatan Meureudu Kabupaten Pidie Jaya.

\section{Populasi, Metode dan Teknik Pengumpulan Data}

Populasi dalam penelitian ini adalah petani padi sawah irigasi yang termasuk dalam golongan petani pemilik-penggarap, petani penyakap, petani penyewa dan petani pemegang gadai. Pengambilan sampel berdasarkan sistem penguasaan lahan sebesar $15 \%$ (Arikunto 2008). Besarnya populasi dari dua desa adalah sebanyak 454 orang petani. Dengan demikian besarnya sampel yang diambil adalah 68 orang petani.

Metode yang digunakan dalam penelitian ini adalah metode survey melalui wawancara langsung kepada petani dengan menggunakan daftar pertanyaan atau kuisioner. Teknik pengambilan sampel ditentukan dengan cara stratified random sampling. Jenis data yang digunakan dalam penelitian ini adalah data primer dan data sekunder.

\section{Model Analisis}

Seluruh data yang diperoleh dalam penelitian ini dikumpulkan, ditabulasi kemudian dianalisis baik secara kuantitatif. Pengujian hipotesis dilakukan dengan menggunakan analisis biaya produksi, penerimaan, pendapatan, Revenue cost ratio $(\mathrm{R} / \mathrm{C})$ dan Break event point (BEP). Adapun Persamaan biaya produksi adalah sebagai berikut.

$$
\mathbf{T C}=\mathbf{T F C}+\mathbf{T V C}
$$

$\begin{array}{lll}\text { Keterangan: } & \text { TC } & =\text { Total biaya produksi }(\mathrm{Rp}) \mathrm{p} \\ & \text { TFC } & =\text { Biaya tetap }(\mathrm{Rp}) \\ \text { TVC } & =\text { Biaya variabel }(\mathrm{Rp})\end{array}$

Analisis Pendapatan Usahatani Padi Berdasarkan Status Penguasaan Lahan Sawah Irigasi Di Kecamatan 
Biaya produksi adalah seluruh biaya yang dikeluarkan oleh produsen dalam mengusahakan usahataninya untuk mendapatkan hasil yang maksimal. Biaya terdiri dari dua kategori yaitu biaya tetap (fixed cost) dan biaya tidak tetap (variable cost). Sedangkan biaya total merupakan jumlah dari keseluruhan biaya produksi yang dikeluarkan dalam sekali produksi (Soekartawi,1995).

Penerimaan total usahatani merupakan nilai produk dari usahatani yaitu harga produk dikalikan dengan total produksi dalam periode tertentu.

$$
\begin{array}{rll} 
& \mathbf{T R}=\mathbf{P} \times \mathbf{Q} \\
\text { Keterangan: } & \text { TR } & =\text { Total penerimaan }(\mathrm{RP}) \\
\mathrm{P} & =\text { Harga jual produk }(\mathrm{Rp} / \mathrm{Kg}) \\
\mathrm{Q} & =\text { Jumlah produksi }(\mathrm{Kg})
\end{array}
$$

Pendapatan adalah Pendapatan petani dari usahatani padi sawah dirumuskan :

$$
\begin{aligned}
& \text { Keterangan: } \pi \quad=\text { Pendapatan }(\mathrm{Rp}) \\
& \boldsymbol{\pi}=\mathbf{T R}-\mathbf{T C} \\
& \mathrm{TR}=\text { Total penerimaan }(\mathrm{Rp}) \\
& \mathrm{TC}=\text { Total biaya produksi }(\mathrm{Rp})
\end{aligned}
$$

$\mathrm{R} / \mathrm{C}$ adalah perbandingan antara nilai total penerimaan (TR) dengan total biaya produksi (TC). Untuk menghitung R/C menggunakan persamaan sebagai berikut:

Keterangan :

$$
\mathrm{R} / \mathrm{C}=\frac{T R}{T C}
$$

$\mathrm{R} / \mathrm{C}$ (Revenue cost ratio) = Perbandingan antara penerimaan dengan biaya

$\mathrm{TR}($ total Revenue $) \quad$ = Total penerimaan usaha $(\mathrm{Rp})$

$\mathrm{TC}($ Total Cost $) \quad=$ Total biaya produksi $(\mathrm{Rp})$

Break event point (BEP) merupakan keadaan yang menggambarkan suatu usahatani yang tidak memperoleh laba dan juga tidak mengalami kerugian. Usahatani akan mencapai keadaan BEP apabila total penerimaan sama dengan total biaya (Prasetya, 2009).

a. BEP produksi

b. BEP harga

$$
\mathrm{BEP}=\frac{\text { total biaya produksi }}{\text { harga jual produk }}
$$

$$
\mathrm{BEP}=\frac{\text { total biaya produksi }}{\text { total Produksi }}
$$

\section{HASIL DAN PEMBAHASAN}

\section{Karakteristik Petani}

Karakteristik petani merupakan atribut atau sifat yang melekat pada diri petani yang dalam hal ini karakteristik tersebut sangat penting bagi petani itu sendiri khususnya untuk membantu meningkatkan efisiensi petani dalam mengadopsi suatu inovasi baru. Karakateristik petani yang diamati dalam penelitian ini terdiri dari 5 variabel meliputi umur, pendidikan, luas lahan, penagalaman dan jumlah tanggungan. 
Tabel 1. Rata-rata Karakteristik Petani Padi Berdasarkan Status Lahan Sawah Beririgasi di Kecamatan Meureudu Kabupaten Pidie Jaya 2017

\begin{tabular}{lllllll}
\hline \multirow{2}{*}{ No } & \multirow{2}{*}{ Karakteristik } & \multirow{2}{*}{ Satuan } & Rata-rata & & \\
\cline { 4 - 6 } & & Milik & Sewa & Sakap & Gadai \\
\hline 1. & Umur & Tahun & 53 & 49 & 44 & 46 \\
2. & Pendidikan & Tahun & 9 & 10 & 9 & 14 \\
3. & Pengalaman & Tahun & 28 & 16 & 17 & 9 \\
4. & Jumlah Tanggungan & Jiwa & 4 & 4 & 3 & 4 \\
5. & Luas Lahan Garapan & Hektar & 0,43 & 0,29 & 0,28 & 0,24 \\
\hline
\end{tabular}

Sumber: Data Primer (diolah), 2017.

\section{Umur}

Berdasarkan Tabel di atas dapat dilihat dari keseluruhan responden dengan 4 status lahan terdiri dari 68 orang petani. Berdasarkan status lahan maka rata-rata umur petani paling tinggi yaitu pada status lahan milik sendiri dengan rata-rata umur petani adalah 53 tahun. Sedangkan rata-rata umur petani paling rendah yaitu pada status lahan sakap dengan rata-rata umur petani adalah 44 tahun, dapat diartikan bahwa rata-rata umur petani padi sawah di Kecamatan Meureudu tergolong kedalam umur yang produktif.

\section{Pendidikan}

Tabel di atas memperlihatkan bahwa tingkat pendidikan yang paling tinggi adalah 14 tahun atau setara dengan D2 yaitu berada pada status lahan gadai. Sedangkan untuk status lahan milik dan sakap pendidikan petani rata-rata masih rendah yaitu 9 tahun atau setara dengan SMP. Rata-rata petani dengan status lahan sewa mempunyai tingkat pendidikan 10 tahun atau setara dengan SMP. Hal ini menunjukkan bahwa sebagian besar petani yang menjadi responden dapat dikatakan sudah mampu memilih keputusan yang akan diambil terkait dalam pengelolaan usahataninya.

\section{Pengalaman Berusahatani}

Ditinjau dari segi pengalaman berusahatani Tabel 5 diatas memperlihatkan bahwa ratarata pengalaman petani dengan status lahan milik memiliki 28 tahun. Selanjutnya petani dengan status lahan sewa dan sakap masing-masing yaitu 16 dan 17 tahun. Sedangkan pengalaman berusahatani paling rendah pada status lahan gadai yaitu 9 tahun.

\section{Jumlah Tanggungan}

Tabel di atas memperlihatkan bahwa rata-rata jumlah tanggungan petani dengan status lahan milik, sewa dan gadai yaitu 4 jiwa. Sedangkan pada status lahan sakap rata-rata jumlah tanggungan yaitu 3 jiwa. Semakin banayak anggota keluarga yang dimiliki petani, maka akan semakin banyak pula pengeluaran petani, sehingga dimungkinkan tidak mampu dalam mengembangakan usahatani yang dikelola dan pendapatan yang diterima cenderung untuk biaya hidup khususya biaya kebutuhan pokok keluarga petani.

\section{Luas Lahan Garapan}

Berdasarkan Tabel di atas rata-rata luas lahan paling besar yaitu pada status lahan milik yang memiliki luas lahan 0,43 hektar. Sedang luas lahan paling kecil yaitu 0,24 hektar pada status lahan gadai. Luas lahan pada status sewa dan sakap masing-masing yaitu 0,28 dan 0,29 hektar. Hal ini menunjukkan bahwa sempitnya luas lahan garapan yang diusahakan oleh petani 
pedesaan merupakan salah satu kendala yang dihadapi oleh petani. Karena luas lahan sangat berpengaruh terhadap produksi dan pendapatan petani padi sawah di daerah penelitian.

\section{Biaya Penyusutan Alat pada Usahatani Padi sawah}

Biaya penyusutan alat termasuk kedalam biaya tetap ( $f i x$ Cost). Penggunaan peralatan pada usahatani padi sawah di daerah penelitian terdiri dari parang, cangkul, garu dan sprayer. Jumlah peralatan yang digunakan oleh petani tergantung pada luas lahan garapan. Berikut adalah tabel penggunaan peralatan dan biaya penyusutan padi sawah.

Tabel 2. Rata-rata Penggunaan Peralatan dan Biaya Penyusutan pada Usahatani Padi Berdasarkan Status Penguasaan Lahan Sawah Irigasi di Kecamatan Meureudu Kabupaten Pidie Jaya, 2017

\begin{tabular}{|c|c|c|c|c|c|}
\hline \multirow[b]{2}{*}{ No } & \multirow[b]{2}{*}{ Jenis Peralatan } & \multicolumn{2}{|c|}{ Milik Sendiri } & \multicolumn{2}{|c|}{ Sewa } \\
\hline & & $\begin{array}{c}\text { Biaya } \\
(\mathbf{R p} / \mathbf{H a} / \mathbf{M T})\end{array}$ & $\begin{array}{l}\text { Penyusutan } \\
\text { (Rp) }\end{array}$ & $\begin{array}{c}\text { Biaya } \\
(\mathbf{R p} / \mathrm{Ha} / \mathbf{M T})\end{array}$ & $\begin{array}{l}\text { Penyusutan } \\
\text { (Rp) }\end{array}$ \\
\hline 1. & Parang & 166.071 & 6.920 & 207.692 & 8.654 \\
\hline 2. & Cangkul & 169.143 & 7.068 & 192.308 & 8.013 \\
\hline 3. & Garu & 187.500 & 7.813 & 242.308 & 10.096 \\
\hline 4. & Sprayer & 696.429 & 19.345 & 1.038 .462 & 28.846 \\
\hline \multicolumn{2}{|r|}{ Jumlah } & 1.219.143 & 41.146 & 1.680 .770 & 55.609 \\
\hline & & \multicolumn{2}{|c|}{ Sakap } & \multicolumn{2}{|c|}{ Gadai } \\
\hline No & Jenis peralatan & $\begin{array}{c}\text { Biaya } \\
(\mathrm{Rp} / \mathrm{Ha} / \mathrm{MT})\end{array}$ & $\begin{array}{l}\text { Penyusutan } \\
\text { (Rp) }\end{array}$ & $\begin{array}{c}\text { Biaya } \\
(\mathbf{R p} / \mathrm{Ha} / \mathbf{M T})\end{array}$ & $\begin{array}{l}\text { Penyusutan } \\
\text { (Rp) }\end{array}$ \\
\hline 1. & Parang & 217.391 & 9.058 & 247.934 & 10.331 \\
\hline 2. & Cangkul & 181.159 & 7.548 & 206.612 & 8.609 \\
\hline 3. & Garu & 253.623 & 10.586 & 289.256 & 12.052 \\
\hline 4. & Sprayer & 1.086 .957 & 30.193 & 1.239 .669 & 34.435 \\
\hline & Jumlah & 1.739 .130 & 57.367 & 1.983 .471 & 65.427 \\
\hline
\end{tabular}

Sumber: Data Primer (diolah), 2017.

Apabila dilihat berdasarkan status penguasaan lahan maka rata-rata biaya penyusutan terbesar dikeluarkan oleh petani dengan status gadai yaitu Rp. 65.427/Ha/MT. Sedangkan ratarata biaya penyusutan pada petani petani dengan status lahan sakap yaitu Rp. 57.367/Ha/MT, selanjutnya rata-rata biaya penyusutan pada petani penyewa adalah Rp. 55.609/Ha/MT. Biaya rata-rata penyusutan paling rendah yaitu pada petani dengan status lahan milik sendiri yaitu sebesar Rp. 41.146/Ha/MT.

\section{Biaya Sarana Produksi Usahatani Padi Sawah}

Biaya Sarana Produksi adalah seluruh biaya peralatan dan bahan yang digunakan selama proses produksi. Dalam usahatani padi sawah sarana produksi yang digunakan terdiri dari benih, pupuk urea, pupuk ponska, pupuk $\mathrm{KCl}$, hand tractor, mesin panen padi (combine) dan pestisida.

Biaya sarana produksi tertinggi yaitu pada status lahan sewa dengan total biaya produksi mencapai Rp. 2.537.794/Ha/MT. selanjutnya pada status lahan sakap biaya sarana produksi mencapai Rp. 2.516.225/Ha/MT dan pada status lahan gadai total biaya sarana produksi yang dikeluarkan yaitu Rp. 2.434.864/Ha/MT. Biaya sarana produksi terendah yaitu dikeluarkan oleh petani dengan status lahan milik sendiri yaitu Rp. 2.379.065/Ha/MT. 
Tabel 3. Rata-rata Jumlah dan Biaya Sarana Produksi Per Ha pada Usahatani Padi Berdasarkan Status Lahan Sawah Irigasi di Kecamatan Meureudu kabupaten Pidie Jaya, 2017

\begin{tabular}{|c|c|c|c|c|c|}
\hline \multirow[b]{2}{*}{ No } & \multirow[b]{2}{*}{ Sarana produksi } & \multicolumn{2}{|c|}{ Milik sendiri } & \multicolumn{2}{|c|}{ Sewa } \\
\hline & & $\begin{array}{c}\text { Jumlah } \\
\text { Penggunaan } \\
\text { (Kg/Ha/MT) }\end{array}$ & $\begin{array}{c}\text { Jumlah Biaya } \\
\text { (Rp/Ha/MT) }\end{array}$ & $\begin{array}{c}\text { Jumlah } \\
\text { Penggunaan } \\
\text { (Kg/Ha/MT) }\end{array}$ & $\begin{array}{c}\text { Jumlah Biaya } \\
\text { (Rp/Ha/MT) }\end{array}$ \\
\hline 1. & Benih (kg) & 24,04 & 312.546 & 24,01 & 312.133 \\
\hline \multirow[t]{5}{*}{2.} & Pupuk: & & & & \\
\hline & Urea $(\mathrm{kg})$ & 129 & 399.679 & 133 & 416.115 \\
\hline & Phonska (kg) & 146 & 438.482 & 143,2 & 429.615 \\
\hline & TSP (kg) & 95 & 381.996 & 108 & 423.821 \\
\hline & $\mathrm{KCl}(\mathrm{kg})$ & 51 & 508.806 & 53 & 525.000 \\
\hline 3. & Pestisida (ml) & 1.199 & 419.750 & 1.206 & 422.109 \\
\hline \multirow[b]{3}{*}{ No } & Jumlah & \multirow{2}{*}{\multicolumn{2}{|c|}{\begin{tabular}{c}
\multicolumn{2}{c}{2.379 .065} \\
Sakan
\end{tabular}}} & \multirow{2}{*}{\multicolumn{2}{|c|}{$\begin{array}{rr}2.537 .794 \\
\text { Gadai }\end{array}$}} \\
\hline & & & & & \\
\hline & Sarana produksi & $\begin{array}{c}\text { Jumlah } \\
\text { Penggunaan } \\
\text { (Kg/Ha/MT) }\end{array}$ & $\begin{array}{c}\text { Jumlah Biaya } \\
\text { (Rp/Ha/MT) }\end{array}$ & $\begin{array}{c}\text { Jumlah } \\
\text { Penggunaan } \\
\text { (Kg/Ha/MT) }\end{array}$ & $\begin{array}{c}\text { Jumlah Biaya } \\
(\mathrm{Rp} / \mathrm{Ha} / \mathrm{MT})\end{array}$ \\
\hline 1. & Benih (kg) & 25,09 & 326.225 & 24,36 & 316.620 \\
\hline \multirow[t]{5}{*}{2.} & Pupuk: & & & & \\
\hline & Urea (kg) & 138 & 429.058 & 133 & 409.008 \\
\hline & Phonska (kg) & 164 & 491.304 & 148 & 445.041 \\
\hline & TSP (kg) & 82 & 327.536 & 77 & 3307.438 \\
\hline & $\mathrm{KCl}(\mathrm{kg})$ & 51 & 514.493 & 54 & 537.190 \\
\hline 3. & Pestisida (ml) & 1.222 & 427.609 & $1.198,76$ & 419.566 \\
\hline \multicolumn{2}{|r|}{ Jumlah } & & 2.516 .225 & & 2.434 .864 \\
\hline
\end{tabular}

Sumber: Data Primer (diolah), 2017.

\section{Biaya Tenaga Kerja Pada Usahatani Padi Sawah}

Tenaga Kerja adalah daya yang menggerakkan suatu kegiatan untuk menghasilkan barang atau jasa yang mempunyai nilai ekonomis dalam rangka memenuhi kebutuhan masyarakat. Sehingga tenaga kerja merupakan salah satu faktor produksi yang memegang peranan penting dalam berusahatani. Adapun jenis kegiatan yang dilakukan dalam usahatani padi sawah di daerah penelitian meliputi proses persiapan lahan, penanaman, pemupukan, pengendalian hama dan penyakit, penyiangan, pemanenan, dan pengangkutan.

Tabel 4. Rata-rata Penggunaan Tenaga Kerja Per Ha pada Usahatani Padi Berdasarkan Status Penguasaan Lahan Sawah Irigasi di Kecamatan Meureudu Kabupaten Pidie Jaya

\begin{tabular}{llrrrr}
\hline & & \multicolumn{2}{c}{ Milik sendiri } & \multicolumn{2}{c}{ Sewa } \\
\cline { 3 - 6 } No & Fase Kegiatan & HKP/MT & $\begin{array}{c}\text { Total Biaya } \\
\text { (Rp/Ha/MT) }\end{array}$ & HKP/MT & $\begin{array}{r}\text { Total Biaya } \\
\text { (Rp/Ha/MT) }\end{array}$ \\
\hline 1. & Persiapan Lahan & 4 & 366.071 & 4 & 423.077 \\
2. & Penanaman & 13 & 1.000 .279 & 14 & 1.068 .510 \\
3. & Pemupukan & 2 & 248.288 & 2 & 238.782 \\
4. & Penyiangan & 6 & 570.313 & 9 & 614.744 \\
5. & Pengendalian & 2 & 183.036 & 2 & 206.731 \\
6. & Pengangkutan & 4 & 420.759 & 5 & 450.321 \\
\hline \multicolumn{2}{r}{$\quad$ Jumlah } & $\mathbf{2 . 7 6 7 . 0 2 0}$ & $\mathbf{3 . 0 0 2 . 1 6 3}$ \\
\hline
\end{tabular}

Analisis Pendapatan Usahatani Padi Berdasarkan Status Penguasaan Lahan Sawah Irigasi Di Kecamatan 


\begin{tabular}{llrrrr}
\hline & & \multicolumn{2}{c}{ Sakap } & \multicolumn{2}{c}{ Gadai } \\
\cline { 3 - 6 } No & Fase Kegiatan & HKP/MT & $\begin{array}{c}\text { Total Biaya } \\
\text { (Rp/Ha/MT) }\end{array}$ & HKP/MT & $\begin{array}{r}\text { Total Biaya } \\
\text { (Rp/Ha/MT) }\end{array}$ \\
\hline 1. & Persiapan Lahan & 4 & 362.319 & 4 & 371.901 \\
2. & Penanaman & 15 & 1.093 .750 & 14 & 1.045 .971 \\
3. & Pemupukan & 2 & 190.217 & 2 & 232.438 \\
4. & Penyiangan & 7 & 697.464 & 6 & 635.331 \\
5. & Pengendalian & 2 & 199.275 & 2 & 170.455 \\
6. & Pengangkutan & 4 & 434.783 & 4 & 444.215 \\
\hline & $\quad$ Jumlah & & $\mathbf{2 . 9 7 7 . 8 0 8}$ & & $\mathbf{2 . 9 0 0 . 3 1 0}$ \\
\hline
\end{tabular}

Sumber: Data Primer (diolah), 2017.

Tabel di atas menunjukkan bahwa total biaya penggunaan tenaga kerja terbesar terdapat pada status lahan sewa yaitu Rp. 3.002.163/Ha/MT, selanjutnya total biaya penggunaan tenaga kerja pada status lahan sakap yaitu Rp. 2.977.808/Ha/MT. Total biaya penggunaan tenaga kerja pada status gadai sebesar Rp. 2.900.310/Ha/MT, sedangkan total penggunaan biaya tenaga kerja terendah yaitu pada status lahan milik sendiri yaitu sebesar Rp. 2.767.020/Ha/MT.

\section{Total Biaya Produksi pada Usahatani Padi Sawah.}

Biaya produksi merupakan biaya yang dikeluarkan oleh petani selama proses prduksi. Biaya produksi terdiri dari biaya tetap (fix cost) dan biaya tidak tetap (variable cost). Biaya tetap adalah biaya yang selama satu periode tertentu biayanya tetap dan tidak mengalami perubahan walaupun produk yang dihasilkan berubah serta biasanya biaya tersebut dipakai lebih dari satu kali produksi, dalam hal ini biaya tetap adalah biaya penyusutan alat. Sedangkan biaya tidak tetap merupakan biaya produksi yang jumlahnya berubah sesuai dengan jumlah produksi yang dihasilkan, dalam hal ini biaya tidak tetap adalah biaya sarana produksi, biaya tenaga kerja, biaya sewa hand tractor, biaya sewa mesin panen padi dan biaya sewa lahan. Untuk lebih jelasnya berikut total biaya produksi usahatatani padi sawah di Kecamatan Meureudu Kabupaten Pidie Jaya.

Tabel 5. Rata-rata Total Biaya Produksi pada Usahatani Padi Berdasarkan Status Penguasaan Lahan Irigasi di Kecamatan Meureudu Kabupaten Pidie Jaya, Tahun 2017

\begin{tabular}{|c|c|c|c|}
\hline No. & Jenis Biaya & $\begin{array}{l}\text { Milik Sendiri } \\
\quad(\mathrm{Rp} / \mathrm{Ha})\end{array}$ & $\begin{array}{l}\text { Sewa } \\
(\mathrm{Rp} / \mathrm{Ha})\end{array}$ \\
\hline \multicolumn{4}{|c|}{ Biaya Tetap (Fix Cost) } \\
\hline & Biaya Penyusutan Peralatan & 41.146 & 55.609 \\
\hline \multicolumn{4}{|c|}{ Biaya tidak Tetap (Variable Cost) } \\
\hline & Biaya Sarana Produksi & 2.379 .065 & 2.537 .794 \\
\hline & Biaya Tenaga Kerja & 2.767 .020 & 3.002 .163 \\
\hline & Sewa Hand Tractor (unit) & 800.000 & 812.308 \\
\hline & $\begin{array}{l}\text { Sewa Mesin Panen Padi } \\
\text { (unit) }\end{array}$ & 2.800 .000 & 2.843 .077 \\
\hline 6. & Biaya Sewa lahan & 5.376 .000 & 5.317 .692 \\
\hline \multicolumn{2}{|c|}{ Total Biaya Produksi } & 14.149 .265 & 14.544 .284 \\
\hline \multicolumn{2}{|c|}{ No. Jenis Biaya } & $\begin{array}{c}\text { Sakap } \\
\text { (Rp/Ha) }\end{array}$ & $\begin{array}{c}\text { Gadai } \\
\text { (Rp/Ha) }\end{array}$ \\
\hline $\begin{array}{l}\text { Biay } \\
1 . \\
\text { Biay }\end{array}$ & $\begin{array}{l}\text { a Tetap (Fix Cost) } \\
\text { Biaya Penyusutan Peralatan } \\
\text { a tidak Tetap (Variable Cost) }\end{array}$ & 57.367 & 65.427 \\
\hline
\end{tabular}

Analisis Pendapatan Usahatani Padi Berdasarkan Status Penguasaan Lahan Sawah Irigasi Di Kecamatan 


\begin{tabular}{rlrr}
\hline 2. & Biaya Sarana Produksi & 2.516 .225 & 2.434 .864 \\
3. & Biaya Tenaga Kerja & 2.977 .808 & 2.900 .310 \\
4. & Sewa Hand Tractor (unit) & 805.797 & 800.000 \\
5. & Sewa Mesin Panen Padi & 2.820 .290 & 2.800 .000 \\
& (unit) & 5.414 .957 & 5.367 .000 \\
6. & Biaya Sewa lahan & 14.596 .066 & 14.377 .427 \\
\hline Total Biaya Produksi
\end{tabular}

Sumber: Data Primer (diolah), 2017.

Tabel diatas menunjukkan bahwa rata-rata total biaya produksi per musim tanam yang dikeluarkan pada usahatani padi sawah di Kecamatan Meureudu Kabupaten Pidie Jaya tertinggi yaitu pada status lahan sakap mencapai Rp. 14.596.006/Ha/MT. Selanjutnya total biaya produksi pada status lahan sewa mencapai Rp. 14.544.284/Ha/MT. Sedangkan pada status lahan gadai total biaya produksi mencapai Rp. $14.377 .427 / \mathrm{Ha} / \mathrm{MT}$ dan total biaya produksi terendah dikeluarkan oleh petani dengan status lahan milik sendiri yaitu Rp. 14.149.265/Ha/MT.

Biaya produksi pada usahatani padi sawah berdasarkan status lahan sakap yaitu dikeluarkan oleh petani penyakap dan pemilik lahan. Sistem kerja sama ini disebut sistem sakap atau pola kerja sama dengan perjanjian bagi hasil. Besar pola bagi hasil antara pemilik lahan dengan petani penyakap yaitu $1: 1$. Biaya yang dikeluarkan oleh pemilik lahan yaitu biaya sarana produksi sebesar Rp. 2.379.065/Ha/MT. Selanjutnya biaya sewa lahan sebesar Rp. 5.414.957 Rp/Ha/MT. Sehingga biaya produksi pada pemilik lahan yaitu Rp. 7.794.022 $\mathrm{Rp} / \mathrm{Ha} / \mathrm{MT}$. Dalam hal ini pemilik lahan tidak mengeluarkan biaya tunai untuk biaya sewa lahan karena lahan merupakan miliknya sendiri.

Biaya yang dikeluarkan oleh petani penyakap yaitu biaya penyusutan peralatan sebesar Rp. 57.367/Ha/MT. Selanjutnya biaya tenaga kerja sebesar Rp. 2.977.808/Ha/MT, biaya sewa hand tractor Rp. 805.797 dan biaya sewa mesin panen padi sebesar Rp. 2.820.290/Ha/MT. Dengan demikian total biaya produksi yang dikeluarkan oleh petani yaitu sebesar Rp. 6.661.262/Ha/MT. Dalam hal ini petani penyakap tidak menanggung biaya sewa lahan namun nantinya pendapatan yang diperoleh akan dibagi dengan pemilik lahan.

\section{Produksi, Harga Jual Produk dan Penerimaan}

Produksi yang dimaksud pada penelitian ini adalah barang atau produk yang dihasilkan pada usahatani padi sawah dalam satuan kilogram, sedangkan nilai produksi merupakan penerimaan kotor yang diperoleh dari hasil produksi per petani dikalikan dengan harga jual yang dinyatakan dalam satuan uang rupiah, harga yang dimaksudkan adalah harga jual produk yang berlaku saat penelitian.

Tabel 6. Rata-rata Produksi, Harga Jual Produk, dan Penerimaan pada Usahatani Padi Berdasarkan Status Penguasaan Lahan Sawah Irigasi di Kecamatan Meureudu Kabupaten Pidie Jaya

\begin{tabular}{lcrrrrr}
\hline \multirow{2}{*}{ No. } & \multirow{2}{*}{ Uraian } & \multirow{2}{*}{ Satuan } & \multicolumn{4}{c}{ Total Biaya } \\
\cline { 4 - 7 } & & Milik Sendiri & \multicolumn{1}{c}{ Sewa } & \multicolumn{1}{c}{ Sakap } & \multicolumn{1}{c}{ Gadai } \\
\hline 1. & Produksi & $\mathrm{Kg} / \mathrm{Ha}$ & 5.350 & 5.416 & 5.387 & 5.346 \\
2. & Harga Jual & $\mathrm{Rp} / \mathrm{Kg}$ & 4.200 & 4.200 & 4.200 & 4.200 \\
\hline Penerimaan $/ \mathrm{Ha}$ & $\mathrm{Rp} / \mathrm{MT}$ & $\mathbf{2 2 . 4 7 1 . 5 0 0}$ & $\mathbf{2 2 . 7 4 6 . 2 3 1}$ & $\mathbf{2 2 . 6 2 5 . 2 1 7}$ & $\mathbf{2 2 . 4 5 2 . 6 4 5}$ \\
\hline
\end{tabular}

Sumber: Data primer (diolah), 2017. 
Penerimaan pada usahatani padi sawah per hektar permusim tanam terbesar yaitu pada status lahan sewa dengan rata-rata penerimaan mencapai Rp. 22.746.231/Ha/MT. Selanjutnya rata-rata penerimaan pada status lahan sakap mencapai Rp. 22.625.217 /Ha/MT. Sedangkan rata-rata penerimaan pada status lahan milik sendiri yaitu Rp. $22.471 .500 / \mathrm{Ha} / \mathrm{MT}$ dan rata-rata penerimaan terendah yaitu pada status lahan milik yaitu Rp. 22.454.645/Ha/MT.

\section{Pendapatan Usahatani Padi sawah}

Pendapatan usahatani dalam penelitian ini merupakan selisih dari nilai produksi dengan total biaya produksi yang dikeluarkan baik biaya tetap maupun tidak tetap. Pendapatan yang diperoleh oleh petani dengan status lahan milik, sewa, sakap dan gadai didaerah penelitian berbeda-beda.

Tabel 7. Rata-rata Pendapatan Usahatani Padi Berdasarkan Status Penguasaan Lahan Sawah Irigasi di Kecamatan Mereudu Kabupaten Pidie jaya, Tahun 2017

\begin{tabular}{llrrrr}
\hline \multirow{2}{*}{ No. } & \multirow{2}{*}{ Uraian } & \multicolumn{4}{c}{ Total Biaya $(\mathrm{Rp} / \mathrm{Ha} / \mathrm{MT})$} \\
\cline { 3 - 6 } & & \multicolumn{1}{c}{ Milik } & \multicolumn{1}{c}{ Sewa } & \multicolumn{1}{c}{ Sakap } & \multicolumn{1}{c}{ Gadai } \\
\hline 1. & Total Biaya Produksi & 14.149 .265 & 14.544 .284 & 14.596 .006 & 14.377 .427 \\
2. & Penerimaan & 22.471 .500 & 22.746 .231 & 22.625 .217 & 22.454 .645 \\
\hline & Pendapatan & $\mathbf{8 . 3 2 2 . 2 3 5}$ & $\mathbf{8 . 2 0 1 . 9 4 7}$ & $\mathbf{8 . 0 2 9 . 1 5 1}$ & $\mathbf{8 . 0 7 5 . 2 1 8}$
\end{tabular}

Sumber: Data primer (diolah), 2017.

Tabel di atas menjelaskan tentang rata-rata pendapatan per hektar per musim tanam yang didapat pada usahatani padi sawah berdasarkan status penguasaan lahan. Pada tabel tersebut dapat dilihat bahwa pendapatan tertinggi yaitu pada petani dengan status lahan milik yaitu sebesar Rp. 8.322.235/Ha/MT, selanjutnya pendapatan petani dengan status lahan sewa yaitu sebesar Rp. 8.201.947/Ha/MT. Sedangkan pendapatan petani dengan status lahan gadai yaitu sebesar Rp. 8.075.218/Ha/MT. Pendapatan terendah yaitu pada status lahan sakap sebesar Rp. 8.029.151/Ha/MT.

Status penguasaan lahan pemilik yang menggarap lahan sawahnya sendiri akan mendapatkan tambahan pendapatan untuk biaya tidak tunai yaitu biaya sewa lahan sebesar Rp.5.376.000/Ha/MT, sehingga pendapatan yang diperoleh oleh petani pemilik penggarap yaitu sebesar Rp. 13.698.235/Ha/MT. Begitu juga dengan status lahan gadai, petani yang menggarap lahan dengan status gadai juga tidak mengeluarkan biaya sewa lahan sebesar Rp. 5.367.000/Ha/MT biaya tersebut menjadi tambahan untuk pendapatan yang diperoleh. Sehingga pendapatan petani dengan status lahan gadai yaitu sebesar Rp. 13.396.151/Ha/MT.

Status penguasaan lahan sakap akan mendapatkan tambahan pendapatan untuk biaya tidak tunai yaitu biaya sewa lahan sebesar Rp. 5.414.957/Ha/MT, sehingga pendapatan yang diperoleh pada status lahan sakap dengan tambahan biaya sewa lahan yaitu Rp. 13.444.108/Ha/MT. Selanjutnya pendapatan yang diterima oleh pemilik lahan dan petani penyakap dengan perbandingan 1 : 1 yaitu sebesar Rp. 6.722.054/Ha/MT.

\section{Revenue Cost Ratio (R/C)}

Untuk mengetahui perbandingan antara total penerimaan dengan keseluruhan biaya yang dikeluarkan dalam mendukung kegiatan operasional usahatani padi sawah berdasarkan status penguasaan lahan di Kecamatan Meureudu Kabupaten Pidie Jaya dapat digunakan persamaan Revenue Cost Ratio (R/C). Berdasarkan hasil penelitian didapati nilai Revenue Cost Ratio (R/C) pada tabel berikut ini. 
Tabel 8. Nilai R/C pada Usahatani Padi Berdasarkan Status Penguasaan Lahan Sawah Irigasi di Kecamatan Meureudu Kabupaten Pidie Jaya, Tahun 2017

\begin{tabular}{rlrrrr}
\hline No. & \multicolumn{1}{c}{ Uraian } & Milik & Sewa & Sakap & \multicolumn{1}{c}{ Gadai } \\
\hline 1 & $\begin{array}{l}\text { Penerimaan } \\
\text { (Rp/Ha/MT) }\end{array}$ & 22.471 .500 & 22.746 .231 & 22.625 .217 & 22.454 .645 \\
2 & $\begin{array}{l}\text { Biaya Produksi } \\
\text { (Rp/Ha/MT) }\end{array}$ & 14.149 .265 & 14.544 .284 & 14.596 .006 & 14.377 .427 \\
\hline & R/C & 1,59 & 1,56 & 1,55 & 1,56 \\
\hline
\end{tabular}

Sumber: Data primer (diolah), 2017.

Berdasarkan tabel di atas dapat dilihat besarnya $\mathrm{R} / \mathrm{C}$ pada usahatani padi sawah terbesar pada status lahan milik yaitu 1,59 artinya setiap penambahan Rp. 1,00 biaya yang dikeluarkan petani akan menghasilkan penerimaan sebesar Rp. 1,59. Sehingga R/C > 1, maka usahatani padi sawah pada status lahan milik menguntungkan. Selanjutnya R/C pada status lahan gadai yaitu sebesar 1,56, artinya setiap penambahan Rp. 1,00 biaya yang dikeluarkan petani akan menghasilkan penerimaan sebesar Rp. 1,56, dengan kata lain $\mathrm{R} / \mathrm{C}>1$, maka usahatani padi sawah pada status lahan gadai menguntungkan. Sedangkan pada status lahan sakap R/C yang didapat adalah sebesar 1,56, artinya setiap penambahan Rp. 1,00 biaya yang dikeluarkan petani kan menghasilkan penerimaan sebesar Rp. 1,56. Sehingga R/C > 1, maka usahatani padi sawah pada status lahan sakap menguntungkan. Nilai R/C terendah yaitu pada status lahan sewa dengan $\mathrm{R} / \mathrm{C}$ sebesar 1,55 namun usahatani pada status lahan sewa juga menguntungkan karena $\mathrm{R} / \mathrm{C}>1$.

\section{Break Event Point (BEP)}

Untuk mengetahui titik impas harga dan produksi pada usahatani padi sawah berdasarkan status penguasaan lahan di Kecamatan Meureudu Kabupaten Pidie Jaya dapat digunakan persamaan Break event point (BEP). Berdasarkan hasil penelitian didapati nilai BEP pada tabel berikut ini.

Tabel 9. Nilai BEP Produksi dan BEP Harga pada Usahatani Padi Berdasarkan Status Penguasaan Lahan Sawah Irigasi di Kecamatan Meureudu Kabupaten Pidie Jaya, Tahun 2017

\begin{tabular}{ccccrrr}
\hline No & \multirow{2}{*}{ Uraian } & Satuan & \multicolumn{1}{c}{ Milik } & \multicolumn{1}{c}{ Sewa } & \multicolumn{1}{c}{ Sakap } & \multicolumn{1}{c}{ Gadai } \\
\hline $\boldsymbol{1}$ & Total Biaya & $\mathrm{Rp} / \mathrm{MT}$ & 14.149 .265 & 14.544 .284 & 14.596 .006 & 14.377 .427 \\
& Produksi & & & & \\
2 & Harga Produk & $\mathrm{Rp} / \mathrm{Kg}$ & 4.200 & 4.200 & 4.200 & 4.200 \\
3 & Total Produksi & $\mathrm{Kg} / \mathrm{MT}$ & 5.350 & 5.416 & 5.387 & 5.346 \\
\hline & BEP Produksi & $\mathbf{( K g )}$ & 3.369 & 3.463 & 3.475 & 3.423 \\
\hline & BEP Harga & $\mathbf{( R p / K g})$ & 2.645 & 2.685 & 2.709 & 2.689 \\
\hline
\end{tabular}

Sumber: Data primer (diolah), 2017.

Berdasarkan tabel di atas Nilai BEP produksi pada status lahan sewa yaitu $3.463 \mathrm{~kg}$, artinya pada saat jumlah produksi $3.463 \mathrm{~kg}$, usahatani padi sawah berada padi titik impas. Sedangkan BEP harga pada status lahan sewa yaitu Rp. 2.685, artinya pada saat harga padi Rp. $2.685 / \mathrm{kg}$, petani telah berada pada titik impas atau balik modal. Selanjutnya Nilai BEP produksi pada status lahan sakap yaitu $3.475 \mathrm{~kg}$, pada saat jumlah produksi $3.475 \mathrm{~kg}$, usahatani padi sawah berada padi titik impas. Sedangkan BEP harga pada status lahan sakap yaitu Rp. 
2.709, artinya pada saat harga padi Rp. $2.709 / \mathrm{kg}$, petani telah berada pada titik impas atau balik modal. Begitu pula pada status lahan gadai nilai BEP produksi yaitu $3.423 \mathrm{~kg}$, pada saat jumlah produksi $3.423 \mathrm{~kg}$, usahatani padi sawah berada padi titik impas. Sedangkan BEP harga pada status lahan gadai yaitu Rp. 2.689, artinya pada saat harga padi Rp. $2.689 / \mathrm{kg}$, petani telah berda pada titik impas atau balik modal. Pada status lahan milik nilai BEP produksi yaitu $3.369 \mathrm{~kg}$, pada saat jumlah produksi $3.369 \mathrm{~kg}$, usahatani padi sawah berada padi titik impas. Sedangkan BEP harga pada status lahan sewa yaitu Rp2.645, artinya pada saat harga padi Rp. $2.645 / \mathrm{kg}$, petani telah berda pada titik impas atau balik modal.

\section{SIMPULAN DAN SARAN}

Hasil analisis pada usatahani padi di Kecamatan Meureudu Kabupaten Pidie Jaya berdasarkan status penguasaan lahan sawah irigasi memperoleh Pendapatan. Pendapatan tertinggi yaitu pada petani dengan status lahan milik sebesar Rp. 8.322.235/Ha/MT, selanjutnya pendapatan petani dengan status lahan sewa yaitu sebesar Rp. 8.201.947/Ha/MT. Sedangkan pendapatan petani dengan status lahan gadai sebesar Rp. 8.075.218/Ha/MT. Pendapatan terendah yaitu pada status lahan sakap mencapai Rp. 8.029.151/Ha/MT. Sehingga pendapatan yang diperoleh oleh petani penyakap dan pemilik lahan pada sistem bagi hasil masing-masing sebesar Rp. 6.722.054/Ha/MT. Adapun saran yang dapat diberikan pada penelitian ini adalah sebaiknya petani memilih sistem sewa jika tidak mempunyai lahan sawah dan ingin menggarap lahan milik orang lain dalam mengusahakan usahataninya hal ini dikarenakan besarnya pendapatan yang akan didapatkan pada sistem sewa lebih tinggi dibandingkan dengan sistem sakap.

\section{DAFTAR PUSTAKA}

Arikunto, Suharsimi. 2008. Prosedur Penelitian : Suatu Pendekatan Praktek. PT Rineka Cipta, Jakarta.

Mudakir, B. 2011. Produktivitas Lahan Dan Distribusi Pendapatan Berdasarkan Status Penguasaan Lahan Pada Usaha Tani Padi (Kasus Di Kabupaten Kendal Propinsi Jawa Tengah). Jurnal Dinamika Ekonomi Pembangunan. 1: 1-83. (1).

Prasetya, H dan Lukiastuti. 2009. Manajemen Operasi. Media pressindo, Yogyakarta.

Prisilia, M.Manatar dan Esry H. Laoh.2017. Pengaruh Status Penguasaan Lahan Terhadap Pendapatan Petani Padi di Desa Tumani, Kecamatan Maesaan, Kabupaten Minahasa Selatan. Jurnal Agri-SosioEkonomi Unsrat. 13:55-64 (1).

Setiawan I. 2006. Dinamika struktur dan kultur agraria petani pada berbagai zona agroekosistem di Kecamatan Solokanjeuk, Kecamatan Nagreg dan Kecamatan Lembang, Kabupaten Bandung. Skripsi. Fakultas Pertanian Universitas Padjajaran, Bandung.

Soekartawi.1995.Analisis Usaha Tani. UI Press, Jakarta.

Suharso, P. 2002. Tanah, Petani, Politik Perdesaan. Pondok Edukasi, Solo. 
Suratiyah, K. 2015. Ilmu Usahatani. Edisi Revisi. Penebar Swadaya, Jakarta.

Winarso, B. 2012. Dinamika Pola Penguasaan Lahan Sawah di Wilayah Pedesaan di Indonesia. Jurnal Penelitian Pertanian Terapan. 12:137-149.(3).

Wiradi, G. 2008. Pola penguasaan tanah dan reforma Agraria. Yayasan Obor Indonesia, Jakarta. 